\title{
CLINICAL STUDIES OF THE BLOOD VOLUME. III. CHANGES IN BLOOD VOLUME, VENOUS PRESSURE AND BLOOD VELOCITY RATE IN CHRONIC CONGESTIVE HEART FAILURE
}

\author{
By JOHN G. GIBSON, 2D and WILLIAM A. EVANS, JR. \\ (From the Medical Clinic of the Peter Bent Brigham Hospital and the Department of Medicine, \\ Harvard Medical School, Boston)
}

(Received for publication June 5, 1937)

Knowledge of the changes in blood volume taking place in the course of congestive heart failure is necessary for an understanding of alterations in the dynamics of circulation in that disease. Changes in blood volume in cardiac decompensation reported in the literature are of a conflicting nature. Bock (1), Brown and Rowntree (2), Thompson (3), Schürmeyer (4), Mies (5), using modifications of the original dye method of determining the blood volume; Plesch (6), using the carbon monoxide method, and Ewig and Hinsberg (7) ; using a combination of the two methods, have reported the blood volume as variably increased during cardiac decompensation. The most extensive studies have been made by Wollheim $(8,9,10,11)$, using a modification (12) of the original Keith-Rowntree technique, Levin (13), and Goldbloom and Libin (14). On the basis of their studies these authors have described two types of congestive failure; the so-called "plus" and "minus" types. In the former type, in which failure is characterized by cyanosis, distension of cervical veins, engorgement of the liver, edema and other symptoms and signs of congestion, the volume is said to be above normal during failure and to decrease with compensation. In the latter type, characterized by pallor, poor venous filling, marked respiratory distress and weakness, but no marked edema, the volume is said to be below normal during failure and to increase during compensation.

In this communication we will report the results of our studies in patients in congestive heart failure, selected from the Cardiac Clinic and Medical Wards of the Peter Bent Brigham Hospital. We have employed the method developed by Gregersen, Gibson and Stead (15), as modified for clinical use by us (16). This method measures the plasma volume by means of an azo dye, Evans Blue, and employs the spectrophotometer for colorimetric estimation of dye concentration in serial samples of blood serum. The total blood volume and red cell volume are calculated from hematocrit values of venous blood and the plasma volume. In addition, many observations on venous pressure and circulation time were made by methods previously described (16).

Changes occurring during the transition from the compensated to decompensated state were studied by means of statistical analysis of a large number of single determinations in patients in varying stages of heart disease. Cases were placed in groups according to the severity of symptoms and clinical signs of congestive failure. Changes in the average values of these groups were taken as characteristic of the trend of blood volume, hematocrit, venous pressure and circulation time in progressive congestive failure.

Changes taking place during recovery from decompensation, or during further progression of heart failure were studied by means of repeated determinations in the same individual during the course of his treatment for congestive heart failure in the hospital, or after discharge therefrom. Both methods have certain limitations, but yield results which are mutually complementary and confirmatory and from which valid conclusions as to the true state of circulatory dynamics in heart disease may be drawn.

One of the principal difficulties in a study of this sort is the selection of normal values for comparative purposes. Normal values for venous pressures, circulation times and hematocrits fall within clearly definable limits, and for this study we have employed the average normal values found by us by the methods employed as previously reported (17). The normal blood volume for a given individual can, however, be assigned with less certainty. In a previous communication (17), we stated that the blood volume varied within wide limits in normal persons of varying habitus and proportion of muscle and 
fat. We also stated that, within certain limits, total blood volume in normal persons bore a relationship to height, weight and surface area. It was our opinion that the average of normal values based on either height or surface area obtained in fairly large groups of individuals might offer a reasonable basis for showing changes from the normal volume levels occurring in disease.

It is obvious that weight is altered in certain phases of cardiac disease, owing to the presence of edema fluids during the congestive phase, and also to the cachexia accompanying chronic heart disease, to such a point as to be meaningless for normal volume estimation on the basis of surface area or weight. We have therefore used the least variable of physical measurements, namely, height, as the basis for estimation of normal blood volume in these studies. This procedure has the advantage over using the average total blood volume of a large number of "normal" individuals of varying age, type of build and state of nutrition, of more closely estimating normal volume with respect to the size of the individuals comprising the different groups. While it must be clear that such normal values for individuals only approximate their true basal volume before decompensation set in, we feel that comparison of average deviations from normal of similar groups shows trends of real significance. Similarly, in individuals, increases or decreases of a range greatly in excess of predicted normal values may be taken as evidence of significant changes.

\section{Changes accompanying progressive degrees of congestive heart failure}

Single determinations were made in 99 individuals with clinically proven organic heart disease. Blood volume, venous pressure and circulation time were determined in the basal state in each case. Cases were divided into four groups.

Group I contained patients with valvular heart disease who exhibited no symptoms or signs of cardiac insufficiency. There were seven males and eleven females in this group; with the exception of three females with congenital heart disease all had valvular lesions diagnosed as being of rheumatic origin.

In Group II were placed those patients who had symptoms of cardiac insufficiency; dyspnea on moderate effort, easy fatigue with or without actual limitation of activity, but in whom no physical signs of congestive failure were observed. There were 12 males and 6 females in this group, all of whom had rheumatic valvular disease except one male with luetic aortic insufficiency.

Groups III and IV consisted of patients in frank congestive failure; those with venous pressures above $150 \mathrm{~mm}$. of water being placed in the latter group, as exhibiting the most severe degree of decompensation. Group III contained 12 males and 10 females; 5 of each sex had rheumatic heart disease, one male syphilitic aortic insufficiency, 2 males and one female hypertensive heart disease and the remainder chronic myocarditis. In Group IV were 7 males and 8 females; 2 males and 6 females had rheumatic

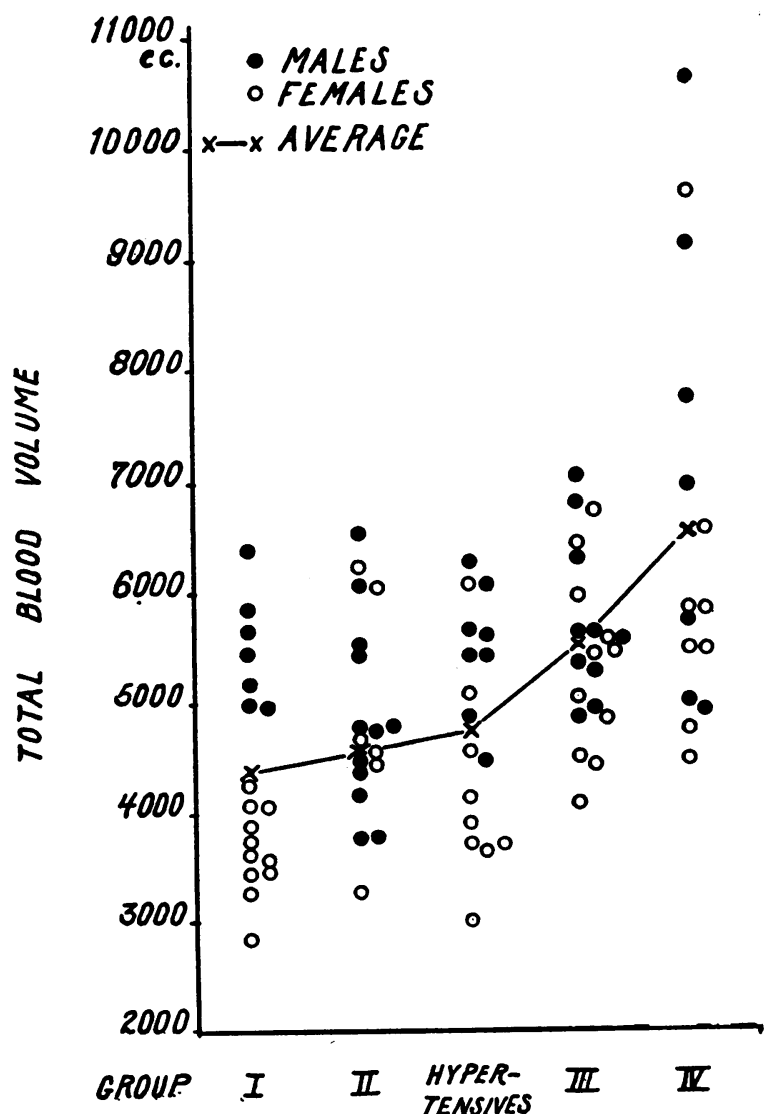

Fig. 1. Increase in Absolute Total Blood Volume in Progressive Heart Fanlure

While a considerable spread in individual volumes occurs the trend of average values indicates a considerable increase in volume over normal levels in congestive heart failure. 
heart disease, 2 males hypertensive heart disease, 1 female constrictive pericarditis of unknown etiology and the remainder chronic myocarditis.

A separate grouping was made of sixteen patients with essential hypertension, of whom 9 were males and 7 females, in whom there was no evidence of renal or cardiac involvement. A few of these complained of fatigue and voluntary restriction of activity, but because of the difficulty of ascribing these symptoms to cardiac disability no attempt was made to class these patients in either of the first two groups. During the period of observation the systolic blood pressure was above $150 \mathrm{~mm}$. of mercury.

TABLE I

Changes in blood volume, hematocrit, venous pressure and circulation time in progressive stages of congestive heart failure

\begin{tabular}{|c|c|c|c|c|c|c|c|c|c|}
\hline \multirow{3}{*}{ Group } & \multirow{2}{*}{\multicolumn{2}{|c|}{$\begin{array}{l}\text { Num- } \\
\text { ber of } \\
\text { cases }\end{array}$}} & \multirow{3}{*}{$\begin{array}{c}\text { Average } \\
\text { predicted } \\
\text { total } \\
\text { blood } \\
\text { volume } \\
\text { based on } \\
\text { height }\end{array}$} & \multirow{3}{*}{\multicolumn{2}{|c|}{$\begin{array}{l}\text { Total } \\
\text { deter- } \\
\text { mined } \\
\text { blood } \\
\text { volume }\end{array}$}} & \multicolumn{4}{|c|}{ Average values for groups } \\
\hline & & & & & & \multirow{2}{*}{$\begin{array}{c}\text { Devia- } \\
\text { tion } \\
\text { from } \\
\text { pre- } \\
\text { dicted } \\
\text { normal }\end{array}$} & \multirow[b]{2}{*}{$\begin{array}{l}\text { Hema- } \\
\text { tocrit }\end{array}$} & \multirow[b]{2}{*}{$\begin{array}{l}\text { Ve- } \\
\text { nous } \\
\text { pres- } \\
\text { sure }\end{array}$} & \multirow[b]{2}{*}{$\begin{array}{l}\text { Cir- } \\
\text { cula- } \\
\text { tion } \\
\text { time }\end{array}$} \\
\hline & $\frac{\Xi}{\Xi ّ}$ & 总 & & & & & & & \\
\hline I & 7 & 11 & $\begin{array}{c}c c . \\
4567\end{array}$ & $\begin{array}{c}c c . \\
4348\end{array}$ & $\begin{array}{l}c c . \\
\text { per } \\
k g m . \\
79.0\end{array}$ & $\begin{array}{l}\text { per cent } \\
-4.8\end{array}$ & $\begin{array}{c}\text { per } \\
\text { cent } \\
\text { of cells } \\
41.1\end{array}$ & $\begin{array}{c}\underset{\mathrm{Hm}}{\mathrm{mm}} \mathrm{O} \\
77\end{array}$ & $\begin{array}{l}\text { sec- } \\
\text { onds } \\
17.5\end{array}$ \\
\hline II & $\overline{12}$ & $\overline{6}$ & 4336 & 4524 & $\overline{76.7}$ & +4.4 & 45.2 & 75.5 & 24.2 \\
\hline $\begin{array}{c}\text { Hyper- } \\
\text { ten- } \\
\text { sives }\end{array}$ & 7 & 9 & 4573 & 4714 & 67.9 & +2.7 & 43.9 & 77.5 & 20.0 \\
\hline III & $\overline{12}$ & $\overline{10}$ & 4656 & 5600 & $\overline{91.5}$ & +22.3 & 44.4 & 107 & 37 \\
\hline IV & 7 & 8 & 4264 & 6543 & 97.0 & +55.3 & 45.6 & 206 & 46.7 \\
\hline
\end{tabular}

The results of these observations are presented in Figure 1 and Table $I$. While in each group there was a considerable spread in the individual values for blood volume, hematocrit, venous pressure and circulation time, the trend of the average values for each of these groups, namely, a progressive increase above normal with advancing decompensation is definite.

The average percentage deviation from normal of each group is shown in Figure 2. The value for Groups I and II may be considered to be within normal limits. With the onset of physical signs of congestive failure (Group III) a large increase above normal, amounting to 22.3 per cent occurs, while in severe failure (Group IV) the increase above normal is 55.3 per cent. In

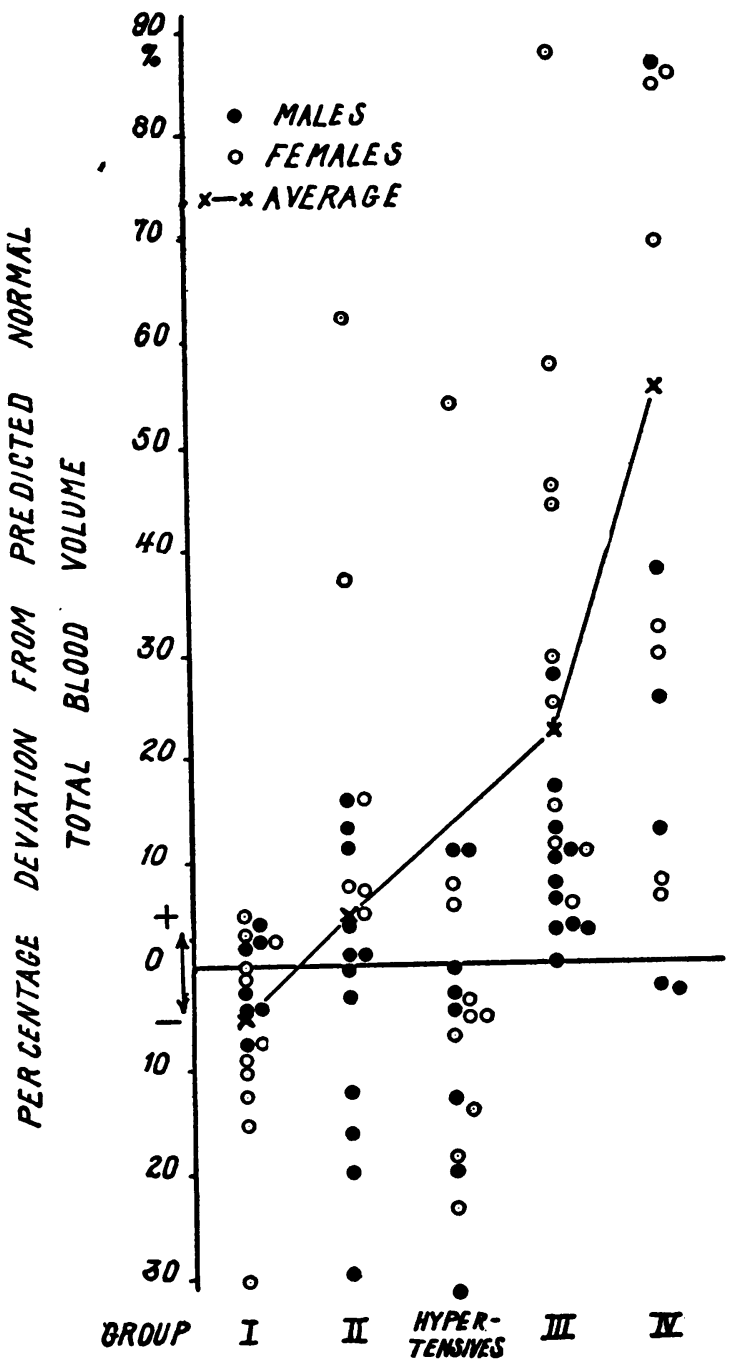

Fig. 2. The Percentage Increase of Average Figures above Predicted Normal Blood Volume in Progressive Congestive Heart Failure

A definite increase occurs in Group II, preceding the development of physical signs of congestion. The average percentage above predicted normal total blood volume for the group of compensated hypertensives is 2.7 per cent, and for five hypertensives in congestive failure (included in Groups III and IV), is 36.2 per cent.

the hypertensive group the average value for patients exhibiting no signs of failure, is well within normal limits. In hypertensive patients in failure, however, the total volume is above normal limits, the average elevation above normal of the 5 patients studied being 36.2 per cent. 
TABLE II

Relation of total blood volume and hematocrit to venous pressure and circulation time

\begin{tabular}{c|c|c|c|c|c|c}
\hline \hline \multirow{2}{*}{$\begin{array}{c}\text { Venous } \\
\text { pressure }\end{array}$} & \multicolumn{2}{|c|}{ Number of cases } & $\begin{array}{c}\text { Average } \\
\text { pre- } \\
\text { dicted } \\
\text { total } \\
\text { blood } \\
\text { volume }\end{array}$ & $\begin{array}{c}\text { Total } \\
\text { blood } \\
\text { vol- } \\
\text { ume }\end{array}$ & $\begin{array}{c}\text { Deviation } \\
\text { from } \\
\text { predicted } \\
\text { normal } \\
\text { total } \\
\text { volume }\end{array}$ & $\begin{array}{c}\text { Hema- } \\
\text { tocrit }\end{array}$ \\
\cline { 2 - 6 } $\begin{array}{c}\text { moles } \\
0-74\end{array}$ & 11 & 12 & 4542 & 4800 & $\begin{array}{c}\text { Females } \\
+1.29\end{array}$ & $\begin{array}{c}\text { per cent } \\
\text { of cells } \\
43.7\end{array}$ \\
\hline $75-99$ & 10 & 12 & 4662 & 4700 & +0.9 & 44.6 \\
\hline $100-149$ & 17 & 7 & 4874 & 5730 & +17.6 & 44.6 \\
\hline $150+$ & 7 & 8 & 4264 & 6543 & +53.5 & 44.4 \\
\hline
\end{tabular}

\begin{tabular}{|c|c|c|c|c|c|c|}
\hline \multirow{2}{*}{$\begin{array}{l}\text { Circula- } \\
\text { tion time }\end{array}$} & \multicolumn{2}{|c|}{ Number of cases } & \multirow{2}{*}{$\begin{array}{c}\text { Average } \\
\text { pre- } \\
\text { dicted } \\
\text { total } \\
\text { blood } \\
\text { volume }\end{array}$} & \multirow{2}{*}{$\begin{array}{c}\text { Total } \\
\text { blood } \\
\text { vol- } \\
\text { ume }\end{array}$} & \multirow{2}{*}{$\begin{array}{l}\text { Deviation } \\
\text { from } \\
\text { predicted } \\
\text { normal } \\
\text { total } \\
\text { volume }\end{array}$} & \multirow{2}{*}{$\underset{\text { tocrit }}{\text { Hema- }}$} \\
\hline & Males & Females & & & & \\
\hline seconds & & & $c c$. & $c c$. & per cent & $\begin{array}{l}\text { per cent } \\
\text { of cells }\end{array}$ \\
\hline $0-19$ & 7 & 16 & 4434 & 4330 & +3.6 & 41.7 \\
\hline 20-29 & 17 & 1 & 4790 & 4960 & +3.7 & 44.8 \\
\hline $30-39$ & 5 & 9 & 4335 & 5564 & +28.3 & 43.6 \\
\hline $40+$ & 5 & 7 & 4460 & 5921 & +32.7 & 44.9 \\
\hline
\end{tabular}

The relationship of changes in absolute volume to venous pressure and circulation time is shown in Table II, from which it is apparent that, in general, marked increases in volume take place only when the venous pressure is in excess of 100 $\mathrm{mm}$. and the circulation time slower than $20 \mathrm{sec}-$ onds; and that the degree of elevation in blood volume is directly related to the degree of rise in venous pressure and slowing of the circulation time. It is also apparent that in the increased volume of failure the rise is not equally shared by the plasma and red cell portions, the increase in hematocrit values from Groups I to IV suggesting a slight concentration of the blood as failure progresses.

\section{Changes accompanying restoration of compensa- tion or progression of decompensation}

For this portion of our study serial observations were made in patients in varying degrees of cardiac decompensation while under treatment in the hospital wards. Clinical grouping of these cases has been made, according to the course of the patient's disease; those showing marked improvement; those undergoing fluctuating courses, characterized by periods of improvement and relapse; and those in whom the disease progressed to a fatal termination.

In Table III is shown the course of blood volume, venous pressure, circulation time, and hematocrit in 13 patients in congestive failure in whom bed rest, digitalization and diuresis were accompanied by a return to a compensated state. The underlying etiology in the failure of these patients is as described in the table. In every case the blood volume at the time of the first determination, made at the time of admission to the hospital, was in excess of the normal volume based on body height for that individual, the extremes in elevation ranging from 5.7 to 85.7 per cent. The average value for the entire group is 29.6 per cent above normal.

In all these 13 cases, of varied etiology, a striking decrease in blood volume, venous pressure and a decrease in circulation time occurred during compensation. Decreases in total volume amounted to a liter or more in the majority of cases, the extremes ranging from $220 \mathrm{cc}$. (Number 56, Table III) to $3950 \mathrm{cc}$. (Number 110, Table IV). In general, those patients experiencing the greatest clinical improvement as evidenced by clinical signs, alleviation of symptoms, weight loss and diuresis, had the largest reductions in total volume from failure levels.

The reduction in plasma volume was at first proportionately greater than the reduction in red cell volume. In 9 of the 13 cases summarized in Table III, hematocrit values rose as compensation was restored. Thus, as illustrated in Cases 55,62 , and 147 (Table III), with clinical improvement there was a considerable fall in plasma volume accompanied by a moderate decrease in red cell volume with resultant rise in hematocrit, the change taking place in a comparatively short time. With further improvement, the plasma volume fell but little more, while the red cell volume continued to diminish with resultant decline in hematocrit value.

The reduction in red cell volume varied greatly, a decrease of about 500 cc. taking place during the transition from failure to compensation. The largest reduction encountered was in Case 110 (Table IV), amounting to $1410 \mathrm{cc}$. in a period of 
TABLE III

Observations on 13 patients experiencing distinct clinical improvement under treatment for congestive heart failure

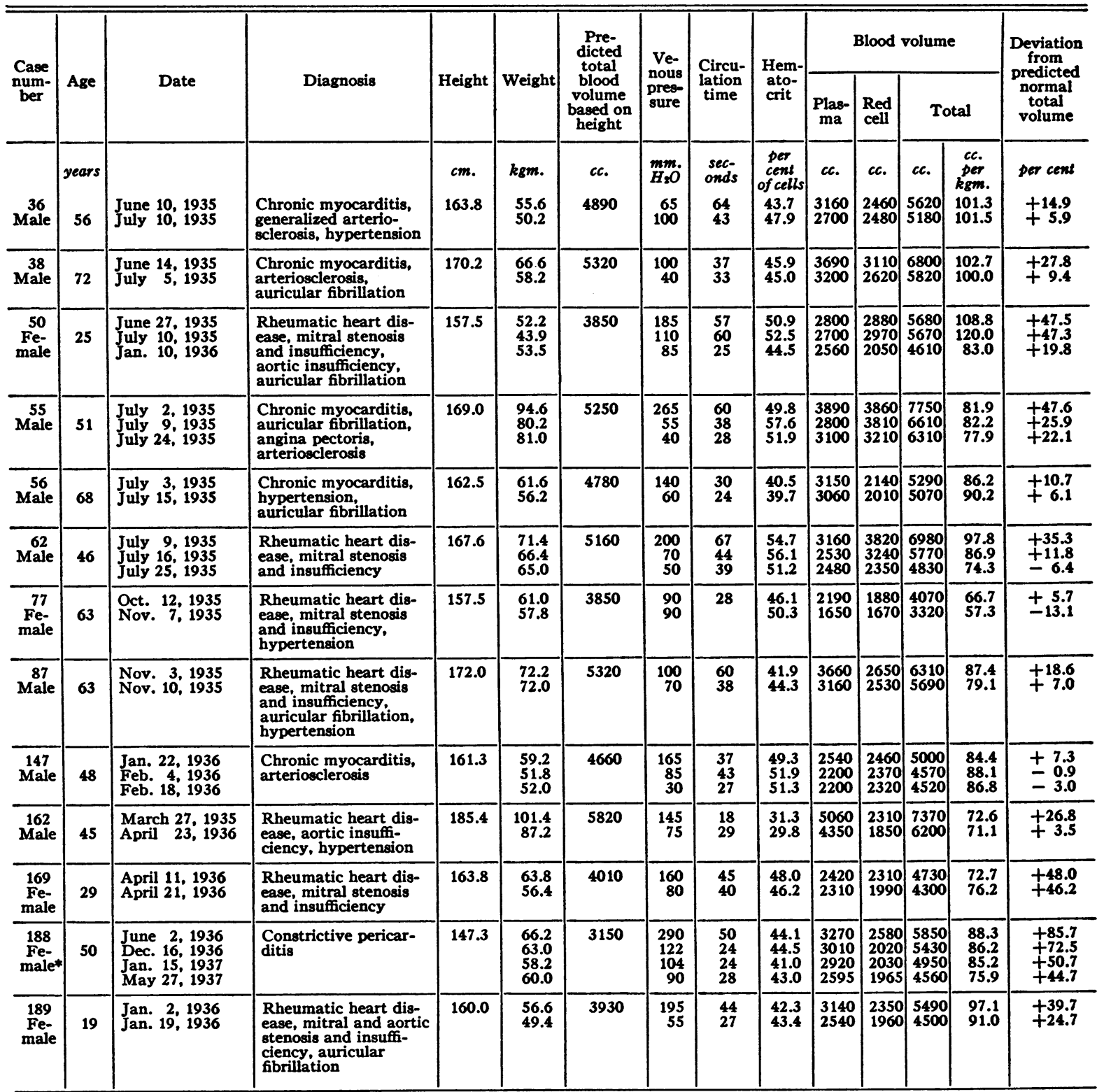

* The second to fourth studies in the patient were made following successful surgical freeing of the pericardial adhesions.

14 days. In none of the cases studied was compensation accompanied by an increase in either plasma or total blood volume.

In contrast, Table IV presents serial studies in 3 cases in whom recovery was not continuous but was interrupted by a relapse to a more severe degree of failure. During these periods of in- creased failure of the circulation, as indicated by clinical signs and symptoms, and frequently by increases in venous pressure and in circulation time, there was an increase in plasma and total volume over levels previously attained during periods of improvement.

Serial studies in 5 cases in whom such fluc- 
tuating courses terminated fatally are presented in Table V. It will be noted that the blood volume remained high or rose as the disease progressed.

\section{DISCUSSION}

Studies of the behavior of Evans Blue after intravenous injection indicate that it does not appear in the pathological transudates of congestive

TABLE IV

Observations on 3 patients exhibiting a relapse while under treatment for severe congestive failure

\begin{tabular}{|c|c|c|c|c|c|c|c|c|c|c|c|c|c|c|}
\hline \multirow{3}{*}{$\begin{array}{c}\text { Case } \\
\text { num- } \\
\text { ber }\end{array}$} & \multirow{3}{*}{$\begin{array}{c}\text { Age } \\
\text { years } \\
35\end{array}$} & \multirow{3}{*}{$\begin{array}{l}\text { Date } \\
\\
\\
\\
10,1935 \\
24,1935 \\
9,1935 \\
28,1935\end{array}$} & \multirow{3}{*}{$\begin{array}{l}\text { Diagnosis } \\
\\
\text { amatic heart dis- } \\
\text { mitral stenosis } \\
\text { insufficiency, } \\
\text { ular fibrillation, } \\
\text { rtension }\end{array}$} & \multirow{3}{*}{$\begin{array}{c}\text { Height } \\
\mathrm{cm} . \\
162.5\end{array}$} & \multirow{3}{*}{$\begin{array}{l}\text { Weight } \\
\\
\text { kgm. } \\
\\
86 \\
75 \\
76 \\
70\end{array}$} & \multirow{3}{*}{$\begin{array}{c}\begin{array}{c}\text { Pre- } \\
\text { dicted } \\
\text { total } \\
\text { blood } \\
\text { volume } \\
\text { based on } \\
\text { height }\end{array} \\
\\
\text { cc. } \\
3980\end{array}$} & \multirow{3}{*}{$\begin{array}{l}\text { Ve- } \\
\text { nous } \\
\text { pres- } \\
\text { sure }\end{array}$} & \multirow{3}{*}{$\begin{array}{c}\begin{array}{c}\text { Circu- } \\
\text { lation } \\
\text { time }\end{array} \\
\text { sec- } \\
\text { onds } \\
43 \\
47 \\
53 \\
53\end{array}$} & \multirow{3}{*}{$\begin{array}{c}\text { Hem- } \\
\text { ato- } \\
\text { crit } \\
\text { per } \\
\text { cent } \\
\text { of cells } \\
41.2 \\
48.2 \\
50.3 \\
49.8\end{array}$} & \multicolumn{4}{|c|}{ Blood volume } & \multirow{2}{*}{$\begin{array}{c}\text { Deviation } \\
\text { from } \\
\text { predicted } \\
\text { normal } \\
\text { total } \\
\text { volume }\end{array}$} \\
\hline & & & & & & & & & & $\begin{array}{c}\text { Plas- } \\
\text { ma }\end{array}$ & $\begin{array}{l}\text { Red } \\
\text { cell }\end{array}$ & \multicolumn{2}{|c|}{ Total } & \\
\hline & & & & & & & & & & $\begin{array}{c}c c . \\
5650 \\
4040 \\
3690 \\
4170\end{array}$ & $\begin{array}{l}c c . \\
3950 \\
3760 \\
3740 \\
4110\end{array}$ & $\begin{array}{c}c c . \\
9600 \\
7800 \\
7430 \\
8280\end{array}$ & $\begin{array}{c}c c . \\
\text { per } \\
k g m . \\
111.3 \\
104.0 \\
97.5 \\
118.2\end{array}$ & $\begin{array}{r}\text { per cent } \\
141.0 \\
96.0 \\
86.5 \\
108.0\end{array}$ \\
\hline $110+$ & 23 & $\begin{array}{l}\text { Nov. 11, } 1935 \\
\text { Nov. 27, } 1935 \\
\text { Dec. 16, } 1935 \\
\text { Jan. } 8,1936\end{array}$ & $\begin{array}{l}\text { Rheumatic heart dis- } \\
\text { ease, mitral stenosis } \\
\text { and insufficiency, } \\
\text { auricular fibrillation }\end{array}$ & 180.0 & $\begin{array}{l}71.8 \\
67.0 \\
75.6 \\
61.6\end{array}$ & 5700 & $\begin{array}{r}230 \\
85 \\
160 \\
130\end{array}$ & $\begin{array}{l}54 \\
39 \\
63 \\
38\end{array}$ & $\begin{array}{l}37.9 \\
39.1 \\
37.7 \\
35.9\end{array}$ & $\begin{array}{l}6610 \\
4240 \\
4960 \\
4280\end{array}$ & $\begin{array}{l}4020 \\
2610 \\
3010 \\
2400\end{array}$ & $\begin{array}{r}10630 \\
6850 \\
7970 \\
6680\end{array}$ & $\begin{array}{l}148.0 \\
102.2 \\
105.2 \\
108.7\end{array}$ & $\begin{array}{l}86.4 \\
20.2 \\
39.8 \\
17.2\end{array}$ \\
\hline $119 \ddagger$ & 50 & $\begin{array}{l}\text { Dec. 2, } 1935 \\
\text { Dec. 9, 1935 } \\
\text { Dec. 16, 1935 } \\
\text { Dec. 23, } 1935 \\
\text { Jan. 18, } 1936\end{array}$ & $\begin{array}{l}\text { Hypertension, } \\
\text { chronic myocarditis, } \\
\text { aortic insufficiency }\end{array}$ & 165.0 & $\begin{array}{l}72.0 \\
64.8 \\
65.2 \\
64.2 \\
58.4\end{array}$ & 4990 & $\begin{array}{r}105 \\
60 \\
50 \\
140 \\
45\end{array}$ & $\begin{array}{l}45 \\
41 \\
56 \\
80 \\
31\end{array}$ & $\begin{array}{l}38.1 \\
42.6 \\
40.7 \\
37.0 \\
36.0\end{array}$ & $\begin{array}{l}3700 \\
3020 \\
3110 \\
4160 \\
3300\end{array}$ & $\begin{array}{l}2270 \\
2230 \\
2130 \\
2460 \\
1850\end{array}$ & $\begin{array}{l}\mathbf{5 9 7 0} \\
\mathbf{5 2 5 0} \\
\mathbf{5 2 4 0} \\
\mathbf{6 6 2 0} \\
\mathbf{5 1 5 0}\end{array}$ & $\begin{array}{r}82.9 \\
80.8 \\
80.4 \\
103.0 \\
88.3\end{array}$ & $\begin{array}{r}19.9 \\
5.4 \\
5.2 \\
32.9 \\
3.4\end{array}$ \\
\hline
\end{tabular}

* Some difficulty was experienced in determining the proper maintenance dose of digitalis in this patient. There was a relapse between the $3 \mathrm{~d}$ and 4 th blood volume determinations.

t Suffered a relapse following an acute upper respiratory infection between the $2 \mathrm{~d}$ and $3 \mathrm{~d}$ blood volume determinations. As the infection subsided this patient's cardiac status improved.

I This patient's course was very fluctuating with periods of improvement and relapse, so that compensation was never well established.

TABLE V

Observations on 5 patients with chronic congestive heart failure exhibiting fluctuating clinical courses terminating fatally

\begin{tabular}{|c|c|c|c|c|c|c|c|c|c|c|c|c|c|c|}
\hline \multirow{3}{*}{$\begin{array}{c}\underset{\text { num- }}{\text { Case }} \\
\\
15 \\
\text { Male* }\end{array}$} & \multirow{3}{*}{$\begin{array}{l}\text { Age } \\
\text { years }\end{array}$} & \multirow{2}{*}{ Date } & \multirow{2}{*}{ Diagnosis } & \multirow{2}{*}{ Height } & \multirow{2}{*}{ Weight } & \multirow{2}{*}{$\begin{array}{l}\text { Pre- } \\
\text { dicted } \\
\text { total } \\
\text { blood } \\
\text { volume } \\
\text { based on } \\
\text { height }\end{array}$} & \multirow{2}{*}{$\begin{array}{l}\text { Ve- } \\
\text { nous } \\
\text { pres- } \\
\text { sure }\end{array}$} & \multirow{2}{*}{$\begin{array}{l}\text { Circu- } \\
\text { lation } \\
\text { time }\end{array}$} & \multirow{2}{*}{$\begin{array}{l}\text { Hem- } \\
\text { ato- } \\
\text { crit }\end{array}$} & \multicolumn{4}{|c|}{ Blood volume } & \multirow{2}{*}{$\begin{array}{l}\text { Deviation } \\
\text { from } \\
\text { predicted } \\
\text { normal } \\
\text { total } \\
\text { volume }\end{array}$} \\
\hline & & & & & & & & & & $\begin{array}{c}\text { Plas- } \\
\text { ma }\end{array}$ & $\begin{array}{l}\text { Red } \\
\text { cell }\end{array}$ & To & tal & \\
\hline & & $\begin{array}{l}\text { March 8, } 1935 \\
\text { March 3, } 1935 \\
\text { Nov. 3, } 1935 \\
\text { Nov. 20, } 1935\end{array}$ & $\begin{array}{l}\text { Rheumatic heart dis- } \\
\text { ease, mitral insuff- } \\
\text { ciency, auricular } \\
\text { fibrillation }\end{array}$ & $\begin{array}{l}c m . \\
167.7\end{array}$ & $\begin{array}{l}\boldsymbol{k g m} . \\
\\
\mathbf{5 2 . 0} \\
\mathbf{5 2 . 0} \\
\mathbf{5 2 . 0} \\
\mathbf{4 8 . 4}\end{array}$ & $\begin{array}{l}c c . \\
5170\end{array}$ & $\begin{array}{r}\mathrm{mm}_{\mathrm{H}} \mathrm{O} \\
105 \\
120 \\
110 \\
90\end{array}$ & $\begin{array}{l}\text { sec- } \\
\text { onds } \\
63 \\
38 \\
83 \\
42\end{array}$ & $\begin{array}{c}\text { per } \\
\text { cent } \\
\text { of cells } \\
44.7 \\
42.5 \\
44.3 \\
38.6\end{array}$ & $\begin{array}{l}c c . \\
2930 \\
3085 \\
2930 \\
2910\end{array}$ & $\begin{array}{l}c c . \\
2370 \\
2275 \\
2330 \\
1820\end{array}$ & $\begin{array}{l}c c . \\
5300 \\
5360 \\
5260 \\
4730\end{array}$ & $\begin{array}{c}c c . \\
\text { per } \\
k g m . \\
101.9 \\
103.0 \\
101.2 \\
97.6\end{array}$ & $\begin{array}{l}\text { per cent } \\
+2.5 \\
+3.7 \\
+1.7 \\
+0.9\end{array}$ \\
\hline $\begin{array}{c}16 \\
\text { Male }\end{array}$ & 50 & $\begin{array}{l}\text { March 11, } 1935 \\
\text { March 23, } 1935 \\
\text { June 22, } 1935 \\
\text { July 17, } 1935 \\
\text { Sept. 10, } 1935\end{array}$ & $\begin{array}{l}\text { Chronic myocarditis, } \\
\text { bundle branch block }\end{array}$ & 170.1 & $\begin{array}{l}\mathbf{5 9 . 2} \\
\mathbf{5 4 . 8} \\
\mathbf{6 1 . 2} \\
\mathbf{5 8 . 4} \\
\mathbf{5 7 . 2}\end{array}$ & 5310 & $\begin{array}{r}75 \\
220 \\
75 \\
50\end{array}$ & $\begin{array}{l}49 \\
47 \\
42 \\
35 \\
39\end{array}$ & $\begin{array}{l}35.3 \\
31.7 \\
38.4 \\
37.1 \\
37.4\end{array}$ & $\begin{array}{l}3715 \\
4320 \\
3370 \\
3490 \\
3420\end{array}$ & $\begin{array}{l}2015 \\
2010 \\
2100 \\
2070 \\
2040\end{array}$ & $\begin{array}{l}\mathbf{5 7 3 0} \\
\mathbf{6 3 3 0} \\
\mathbf{5 4 7 0} \\
\mathbf{5 5 6 0} \\
\mathbf{5 4 6 0} \\
\end{array}$ & $\begin{array}{r}96.8 \\
115.2 \\
89.5 \\
95.2 \\
95.5 \\
\end{array}$ & $\begin{array}{r}+7.9 \\
+19.2 \\
+\quad 6.8 \\
+\quad 4.7 \\
+\quad 2.8\end{array}$ \\
\hline Malet & 42 & $\begin{array}{l}\text { May 10, } 1935 \\
\text { May 23, } 1935\end{array}$ & $\begin{array}{l}\text { Syphilitic aortitis, } \\
\text { aortic insufficiency, } \\
\text { hypertension }\end{array}$ & 168.9 & & 5240 & 110 & $\begin{array}{l}23 \\
25\end{array}$ & $\begin{array}{l}43.8 \\
38.8\end{array}$ & $\begin{array}{l}2530 \\
2960\end{array}$ & $\begin{array}{l}1950 \\
1870\end{array}$ & $\begin{array}{l}4480 \\
4830\end{array}$ & $\begin{array}{l}85.1 \\
88.2\end{array}$ & $\begin{array}{l}-14.5 \\
-7.8\end{array}$ \\
\hline $\begin{array}{c}49 \\
\text { Fe- } \\
\text { male }\end{array}$ & 36 & $\begin{array}{l}\text { June } 26,1935 \\
\text { July } 11,1935\end{array}$ & $\begin{array}{l}\text { Rheumatic heart dis- } \\
\text { ease, mitral stenosis } \\
\text { and insufficiency }\end{array}$ & 158.8 & & 3890 & $\begin{array}{l}215 \\
150\end{array}$ & $\begin{array}{l}57 \\
64\end{array}$ & $\begin{array}{l}50.7 \\
50.0\end{array}$ & $\begin{array}{l}3250 \\
3280\end{array}$ & $\begin{array}{l}33330 \\
\mathbf{3 2 8 0}\end{array}$ & $\begin{array}{l}6580 \\
6560\end{array}$ & $\begin{array}{l}112.2 \\
108.4\end{array}$ & $\begin{array}{l}+67.5 \\
+67.0\end{array}$ \\
\hline $\begin{array}{c}151 \\
\text { Fe- } \\
\text { male }\end{array}$ & 22 & $\begin{array}{l}\text { Feb. 23, } 1936 \\
\text { March 3, } 1936\end{array}$ & $\begin{array}{l}\text { Rheumatic heart dis- } \\
\text { ease, mitral stenosis } \\
\text { and insufficiency, } \\
\text { aortic insufficiency }\end{array}$ & 157.3 & & 3850 & $\begin{array}{r}210 \\
70\end{array}$ & $\begin{array}{l}30 \\
34\end{array}$ & $\begin{array}{l}42.4 \\
40.0\end{array}$ & $\begin{array}{l}2580 \\
2730\end{array}$ & $\begin{array}{l}1890 \\
1820\end{array}$ & $\begin{array}{l}4470 \\
4550\end{array}$ & $\begin{array}{l}104.0 \\
109.5\end{array}$ & $\begin{array}{l}+16.1 \\
+18.2\end{array}$ \\
\hline
\end{tabular}

* This patient underwent the operation of cardiolysis twice during the observation period without relief of symptoms. At no time did he have marked edema.

$\dagger$ This patient had been in chronic failure for 16 years and was extremely cachectic. The predicted normal volume probably represents too high a value. 
heart failure. We have been unable to detect the presence of the dye in edema fluid withdrawn from the legs by Southey tube, or in ascitic or thoracic fluid obtained by paracentesis from patients having large amounts of dye in their blood stream at the time the fluids were obtained. Evans and Gibson (18) showed that Evans Blue does not accumulate in the edema fluids of dogs rendered edematous by plasmapheresis even though a high concentration of dye in the blood stream was maintained by repeated injections while the edema was forming. It seems clear therefore that the presence of edema does not invalidate the method of plasma volume determination employed in this study.

We wish to emphasize the fact that many of the patients studied in this investigation were in a condition of chronic congestive failure, many of them having survived one or more attacks of decompensation. Since this disorder is characterized by a progressive wasting of the blood-holding tissues, it is very probable that the "normal" values for many of the individuals, in a state of decline when the first determinations were made, would be considerably lower than those arbitrarily employed in this study. It is therefore probable that, in a given individual, the percentage increase over levels prevailing in a state of compensation to which blood volume rises at the height of congestive failure is far greater than indicated by the percentage increase from estimated normal volume as described above.

That some degree of elevation of blood volume may precede the development of physical signs of congestive failure is suggested by the data given in Figure 1. An average increase of 4.4 per cent above normal occurred in the patients in Group II, none of whom exhibited any physical signs of congestion but did have definite symptoms of limited cardiac reserve.

We are unable to confirm the finding of the existence of two contrasting types of congestive heart failure as regards the state of the blood volume, the so-called " plus" and " minus" types, described by Wollheim (9), Levin (13), and Goldbloom and Libin (14). All of our patients who could be classified as exhibiting the clinical aspects of the so-called "minus" type of failure (Cases 38, 56, 77, and 36), with clinical improvement experienced fair to moderate diureses and had a decrease in blood volume. Case 77 (Table III) is of particular interest in this regard. This elderly woman with mitral stenosis and hypertension was definitely undernourished, and while the initial volume during frank failure was only slightly above the estimated normal value, the response to therapy was satisfactory, was accompanied by a weight loss of $3.2 \mathrm{kgm}$. following moderate diureses, and the blood volume underwent a reduction of $750 \mathrm{cc}$. We conclude that the conception of a "minus" type of failure is a misconception arising from errors inherent in the techniques employed.

The above authors employed various modifications of the original Keith-Rowntree technique using red dyes and the Dubosq or related types of colorimeters. Graff and Clarke (19) showed that hemolysis of samples could give rise to large erors when red dyes were used. H. P. Smith (20) proved that errors amounting to 25 per cent in either direction could be introduced by the presence of residual dye from previous determinations in the "dye-free" sample. Errors in colorimetry when the Dubosq type of colorimeter is used, as shown by Gregersen, Gibson and Stead (15) and Gibson and Evans (16), due to inequality of dye concentration of standard and sample are of such a nature and degree as to give falsely low values in cases with high volumes (in which the dye is greatly diluted so that the standard is more concentrated than the sample), and falsely high volumes in cases with low values, the degree of error being possibly 20 per cent. We (16) have shown that the mixing of dye in the blood stream is greatly prolonged in congestive heart failure, that an error arises which is in the direction of a falsely low volume when the calculation is based on the dye concentration of samples taken before mixing is complete, and that this error may be as large as 20 per cent in severely decompensated cases. The procedure of using a single sample after injection of the dye involves errors due to dilution of dye by lymph, and to variations in the rate of disappearance from the blood stream.

It is obvious that with all these uncontrolled sources of error inherent in the techniques employed in previously reported studies, two of the most significant of which tend to give falsely low values in subjects with large plasma volumes and 
slowed circulation, the finding of low volumes during failure with increases during compensation is an erroneous one.

\section{CONCLUSIONS}

1. In heart disease the change from the compensated to the decompensated state is accompanied by a progressive increase in the volume of plasma and red cells.

2. This increase is shared to a slightly less extent by the plasma than by the corpuscles, resulting in a slight concentration of the blood.

3. The average degree of increase in blood volume above normal parallels the average degree of elevation of venous pressure and slowing of circulation time.

4. During recovery from congestive failure there is a diminution in both plasma and cell volume, the degree of decrease in plasma in most cases being at first more rapid than that of the corpuscles, resulting in varying degrees of blood concentration. With continued compensation the proportion of cells to plasma returns to within normal limits. The decrease in total volume parallels the degree of clinical improvement.

5. In no case was an increase in volume during recovery from chronic congestive failure observed. Relapses to more severe degrees of circulatory failure are accompanied by maintained elevation of, or further increases in blood volume.

We wish to acknowledge our appreciation of the advice and encouragement of Professor Henry A. Christian and Dr. Samuel A. Levine.

\section{BIBLIOGRAPHY}

1. Bock, A. V., The constancy of the volume of the blood plasma. Arch. Int. Med., 1921, 27, 83.

2. Brown, G. E., and Rowntree, L. G., The volume and composition of the blood, and the changes incident to diuresis, in cases of edema. Arch. Int. Med., 1925, 35, 129.

3. Thompson, W. O., Studies in blood volume. I. The blood volume in myxedema with a comparison of plasma volume changes in myxedema and cardiac edema. J. Clin. Invest., 1926, 2, 477.

4. Schürmeyer, A., Uber Blutmengenbestimmungen bei Herzfehlern. Verhandl. d. deutsch. Gesellsch. f. inn. Med., Kong 40, 1928, 40, 388.
5. Mies, H., Ueber die Wirkung des Strophanthin auf die zirkulierende Blutmenge. Ztschr. f. Kreislaufforsch., 1931, 23, 460 .

6. Plesch, J., Untersuchungen über die Physiologie und Pathologie der Blutmenge. Ztschr. f. klin. Med., 1922, 93, 241.

7. Ewig, W., and Hinsberg, K., Kreislaufstudien. II. Ztschr. f. klin. Med., 1931, 115, 693.

8. Wollheim, E., Kompensation und Dekompensation des Kreislaufs. Klin. Wchnschr., 1928, 7, 1261.

9. Wollheim, E., Zirkulierende Blutmenge, Kompensation und Dekompensation des Kreislaufs. Verhandl. d. deutsch. Gesellsch. f. inn. Med., 1929, 41, 352.

10. Wollheim, E., Zum Problem der Kompensation und Dekompensation des Kreislaufs. Deutsche Med. Wchnschr., 1930, 56, 556.

11. Wollheim, E., Die zirkulierende Blutmenge und ihre Bedeutung für Kompensation und Dekompensation des Kreislaufs. Ztschr. f. klin. Med., 1931, 116, 269.

12. Wollheim, E., Die Bestimmung der zirkulierende Blutmenge. Ztschr. f. klin. Med., 1928, 108, 463.

13. Levin, E., Formas de hipervolemia en la descompensación cardiaca. Rev. argent. de. cardiol., 1935, 2, 17.

14. Goldbloom, A. A., and Libin, I., Clinical studies in circulatory adjustments. I. Clinical evaluation of studies of circulating blood volume. Arch. Int. Med., 1935, 55, 484.

15. Gregersen, M. I., Gibson, J. J., and Stead, E. A., Plasma volume determination with dyes; errors in colorimetry; use of the blue dye T-1824. Am. J. Physiol. (Proc.), 1935, 113, 54.

16. Gibson, J. G., 2d, and Evans, Wm. A., Jr., Clinical studies of the blood volume. I. Clinical application of a method employing the azo dye "Evans Blue" and the spectrophotometer. J. Clin. Invest., 1937, $16,301$.

17. Gibson, J. G., 2d, and Evans, Wm. A., Jr., Clinical studies of the blood volume. II. The relation of plasma and total blood volume to venous pressure, blood velocity rate, physical measurements, age and sex in ninety normal humans. J. Clin. Invest., $1937,16,317$.

18. Evans, Wm. A., Jr., and Gibson, J. G., 2d, The blood volume in diuresis. A study employing the colloidal blue dye T-1824 in dogs rendered edematous by plasmapheresis. Am. J. Physiol., 1937, 118, 251.

19. Graff, S., and Clarke, H. T., Determination of plasma volume. I. The dye method. Arch. Int. Med., 1931, 48, 808.

20. Smith, H. P., Blood volume studies. II. Repeated determinations of blood volume at short intervals by means of the dye method. Am. J. Physiol., 1920, $51,221$. 